\title{
Introduction: Manchu in Transregional History: Diplomacy, Biographies, Textbooks
}

\author{
KATJA PESSL AND JULIA C. SCHNEIDER \\ University of Göttingen \\ Guest Editors \\ Volume 15, 2018 \\ Special Issue: Manchu in Transregional History
}

简介

跨区域史中的满语:外交, 传记, 与课本

Katja Pessl 白雪 and Julia C. Schneider 舍尤莉

哥廷根大学

特邀编辑

2017年9月19日至22日, 我们在哥廷根大学举办了以 “全球史中的满语：一 门清史学家的研究性语言” 为主题的国际座谈会。我们举办座谈会并征集论 文, 不仅仅是希望揭示一种于清史学者有裨益的语言学习方法, 而是意图建 立起满语与全球史的联系, 令学者能够以满语为研究工具, 去探索这类塑造 了现代东亚、中亚和内亚形态的时代材料。我们期待着能够收获超越语言学 和文献学的读者, 也鼓励师生们积极参与满族研究, 为方兴未艾的全球史做 出应有的贡献。以 “全球史中的满语” 为题, 我们冀图将满族研究和 (新) 清史置于全球性的史学框架中去理解, 这一意图近些年来得到了许多响应。 满族研究为我们提供了了解相关区域历史的重要机会, 而我们对这些区域历 史的研究往往不足, 甚至全无了解。

簡介

跨區域史中的滿語:外交, 傳記, 與課本

Katja Pessl 白雪 and Julia C. Schneider 舍尤莉

哥廷根大學

特邀編輯

2017年9月19日至22日, 我們在哥廷根大學舉辦了以 “全球史中的滿語：一 門清史學家的研究性語言” 為主題的國際座談會。我們舉辦座談會並征集論 文, 不僅僅是希望揭示一種於清史學者有裨益的語言學習方法, 而是意圖建 立起滿語與全球史的聯系, 令學者能夠以滿語為研究工具, 去探索這類塑造 
了現代東亞、中亞和內亞形態的時代材料。我們期待著能夠收獲超越語言學 和文獻學的讀者, 也鼓勵師生們積極參與滿族研究, 為方興未艾的全球史做 出應有的貢獻。以 “全球史中的滿語” 為題, 我們冀圖將滿族研究和 (新) 清史置於全球性的史學框架中去理解，這一意圖近些年來得到了許多響應。 滿族研究為我們提供了了解相關區域歷史的重要機會, 而我們對這些區域歷 史的研究往往不足, 甚至全無了解。

Our international symposium "Manchu in Global History: A Research Language for Qing Historians" convened at the University of Göttingen on September 19-22, 2017. Through the symposium and the essays compiled here, we aim to shed light on how scholars engage with Manchu studies in a way that is meaningful not only to Qing historians, but also relevant for approaches to global history. Scholars use the Manchu language as a tool to explore sources from one of the eras that have shaped present-day East, Central, and Inner Asia. Beyond linguistics and philology, this impetus may motivate readers-scholars and students alike- to engage in Manchu studies and contribute to the emerging field of global studies. Framed by the overall theme "Manchu in Global History," our intention was to embed Manchu studies and (new) Qing history in an understanding of history and historiography on a global scale, an endeavour that has gained momentum in recent times. Manchu sources thus provide crucial access to relevant areas of history so far under- and even unstudied.

Combining four thematic panels and a keynote lecture with six Manchu language sessions and tours through special collections held at the University of Göttingen, our symposium invited scholars to simultaneously engage with critical analysis of sources, methods of translation, and research on global history in the past. Over the course of the four-day symposium, participants from universities and research institutions in Asia, North America, and Europe presented individual papers, discussed their approaches, translated Manchu texts, and had the opportunity to see books, manuscripts, and material items from and about Northeast and Inner Asia. In the short report below, we provide an overview of the presented papers, language sessions and keynote lecture, as well as a brief introduction of the documents, archives, and collections visited during the event.

Mark Elliott's (Harvard University) keynote speech was inspiring on several levels. Elliott, one of the doyens of the New Qing History school, reflected on "Manchu Sources and the Problem of Translation." He discussed how readers and particularly historians can capture both the sense and styles of texts in another language and how scholars can transfer key concepts from the original Manchu into their analytical translation. He encouraged the audience to think about the implications of scholarly work across languages and inspired scholars to critically examine their own position and range of choices, tools, and agendas within the process of translating Qing documents. Last 
but not least, he highlighted the challenges of studying Manchu, a language that has lost its traditions of speaking, writing, and reading after one hundred years of neglect.

Manchu language teacher Edward Liang (University of Tübingen) gave lessons guiding the participants through the translation of diverse Manchu texts. In his paper, "A Short Report on the Content Analysis of the Manchu Old Archives" (Dorgi yamun asaraha manju hergen ife dangse; Neige cangben Manwen laodang 內閣藏本滿 文老檔), Liang briefly introduced the Old Archives and explained their relevance as historical sources. Under his careful advice, the participants produced ad hoc translations of passages from well-known Qing textbooks: Manju Nikan hergen-i Cing wen ki meng bithe (Qingwen qimeng 清文啟蒙, 1730), Manju gisun-i oyonggo jorin-i bithe (Qingwen zhiyao 清文指要, 1809), and Sirame banjibuha Nikan hergen-i kamcibuha Manju gisun-i oyonggo jorin bithe (Xubian jian Han-Qingwen zhiyao 續編兼漢清文指 要, 1809). Moreover, we read two sources in Manchu, passages from the Dorgi yamun asaraha manju hergen i fe dangse and the Treaty of Nerchinsk. Finally, we translated passages from a more recent Sibe textbook, the Sibe Nikan gisun tacire bithe (Xi-Han hui bua 锡汉会话, 1992).

On the first day, we visited the historical library collections. Johannes Reckel of the State and University Library Göttingen (SUB) introduced the large Manchu holdings of the library, among them the facsimile of an anatomy atlas in Manchu translation from the Kangxi era, in an edition from Copenhagen (1923), the Anatomie Mandchoue. Participants studied the "Collections and Historical Holdings" of the library, particularly rare manuscripts in diverse Inner and Central Asian languages from the Collection of Baron Georg Thomas von Asch (1729-1807). On the third day, Jens Matuschek introduced us to the Ethnographic Collection of the University of Göttingen, notably to Baron von Asch's Siberia collection, providing fascinating insights and exciting debates regarding Tungusic and other Northeast Asian nomadic cultures.

Twelve speakers presented their papers in four thematic panels. The first two panels focused on source materials in the genre of "Textbooks, Primers, and Dictionaries." Papers in the third and fourth panels engaged with Manchu sources to analyse transregional political history.

The first panel addressed particular "Approaches to the Non-Manchu 'Other' and the World." In her paper, "Writing World History in Manchu: The Reimagining of China and the World in the Last Qing-Published Manchu Textbook," Jiani He (Cambridge University) used a Manchu-Mongol-Chinese Trilingual Textbook as an example to explain how the authors of textbooks expressed their imaginings of the Qing Empire in an increasingly globalised world, and how they conveyed complex values, such as nationhood, sovereignty, and patriotism. Arina Mikhalevskaya (Yale University), in her presentation "A Shift towards Modernity? Textual Analysis of Two EighteenthCentury Chinese-Manchu Manuscripts” about the Huang Qing zhigong tu 皇清職貢 
圖 (Illustrated Tributaries of the Qing Empire, 1761), the Shoupu 獸譜 (Album of Beasts, 1761) and the Niaopu 鳥譜 (Album of Birds, 1761), reflected on the Qing Empire and methodological shifts in defining its place in the world. In "Global Understanding in Manchu Language: A Case Study of the Tulergi gurun i ejetun," Joseph C. Williams (Gakushuin University) analyzed the sources of the Tulergi gurun i ejetun (Gazetteer of Foreign Nations, 1791), a Manchu manuscript of the late eighteenth century and discussed how the Qing Empire engaged with foreign countries by using older Chinese knowledge in such gazetteers and travelogues.

The papers in the second panel, using "Textbooks, Primers, and Dictionaries," focused on the issues of "Health, Space, and Identity." Yves Trachsel (University of Zürich) opened the second panel with his presentation, "Curing Manchu Addictions with Traditional Chinese Medicine: On the Socio-Cultural Paradoxes in ManchuChinese Primers." His analysis of primers enhances our understanding of the everyday lives of common bannermen. Focusing on alcohol as well as tobacco consumption and related health issues, Trachsel elucidated everyday life within the banner garrisons beyond the idealized requirements of the "Manchu Way." Huiying Chen (University of Illinois), in her paper "Ordering of Space in Manchu: Section on Roads and Streets in the 1771 Manchu-Chinese Dictionary," debated how space is regulated in the Manchu language and how the Qing Empire managed crossings and connections among the different peoples and cultures under its rule and beyond. Lars Peter Laamann (SOAS, London) analyzed the Manchu textbook Tanggu Meyen (One Hundred Phrases) in his paper, "Manchu Language Learning and Socio-Linguistic Identity in NineteenthCentury China." He illustrated the methods of language instruction, the cultural messages conveyed, and how they provide insights into everyday preoccupations and ethnic sensitivities in urban centres of the eighteenth and nineteenth centuries.

Switching to the second half of the papers on transregional political history, the third panel, "Manchu as Langue Diplomatique in Inner Asia," opened with Natsagdorj Battsengel's (Mongolian Academy of Sciences) paper titled, "Behind the Treaty of Nerchinsk: The Foredoomed Destiny of the Mongols." Analyzing Russian and Manchu documents dealing with the diplomatic negotiation of the Treaty, Battsengel used a micro-historical approach to highlight the neglected role of Mongolian agency within this process. He followed the fate of Mongol noble Toin Daicing (d. ca. 1689/90) and his family, and recalled diplomatic negotiations after their capture by Russian troops. Ling-Wei Kung (Columbia University), in his paper "Translingual Networking between Ladakh and the Qing Dynasty," emphasised the prominent role of borderlands in the formation of the Qing's worldview by analyzing Qing-Ladakh correspondence and the ways in which such connections influenced the Qing's policy toward Inner Asian affairs. With a close reading and a call for textual awareness of the Treaty of Nerchinsk, Ning Chia (Central College), in her paper "Treaty of Nerchinsk of 1689: The Textual Analy- 
sis and the Manchu buthašara urse (Hunting People) in the Treaty Texts," discussed the Manchu term buthašambi ("to hunt") and argued that the contracting parties, as well as the Jesuits, rearranged the treaty language regarding hunters.

The papers presented in panel four, "Manchu Texts as Sources for Qing Foreign Policy," addressed cross-cultural issues of the Qing Empire's relation with Kazahks, with Korea, and with Tibet. Drawing on newly released archival documents from the Qing dynasty, Bakhyt Ezhenkhan-uli (International Turkic Academy Astana), in his paper "The Lure of Kashgar to Kazakhs in the Second Half of the Eighteenth Century," highlighted the Kazakhs' commercial interest in Kashgaria and the Qing court's policies towards their involvement in the region. By examining trilingual documents from a murder case that occurred in 1761 at the border along the Tumen River, Masato Hasegawa (Max Planck Institute for the History of Science in Berlin) illuminated "Border Crossings and Crime in the Sino-Korean Borderland of the Eighteenth Century," i.e., the relevance of Manchu documents for research of trans-regional connections in the Sino-Korean borderland. Pursuing a biographical approach in "The Qing's Last Kutuktu: Künga Gyeltsen and the Qing state's Tibet Policies from the Tongzhi Restoration to 1912," Max Oidtmann (Georgetown University) reconstructed the exceptional fate of Künga Gyltsen (1835-1895), a monk and military official in the Qing's Inner Asian borderlands, shedding light on the understanding of the nineteenth century Qing Empire and colonialism from a Tibetan perspective.

This special issue was inspired by the desire to collect original contributions in the field of Qing history that shed light on some of the challenging tasks in conducting multi-lingual research in the field of global history. We are most happy to introduce the following four papers, each representing one of the four thematic fields of the conference, to a broader readership of Saksaha. 